Jurnal Cakrawala: Studi Manajemen Pendidikan Islam dan Studi

Sosial P-ISSN: 2580-9385, E-ISSN: 2581-0197

http:/ / ejournal.iainu-kebumen.ac.id/index.php/ cka/ index

\title{
PENYULUHAN PENGELOLAAN SAMPAH DENGAN KONSEP 3R DALAM MENGURANGI LIMBAH RUMAH TANGGA
}

\author{
${ }^{1}$ Trisnawati, O.R,. ${ }^{2}$ Khasanah, N. \\ Fakultas Tarbiyah Institut Agama Islam Nahdlatul Ulama \\ ${ }^{1}$ E-mail : oky.ristya@gmail.com \\ ${ }^{2}$ E-mail : cnung.khasanah@gmail.com
}

\begin{abstract}
Abstrak: Sampah menjadi salah satu permasalahan yang cukup sulit di tangani di Indonesia. Keberadaan limbah rumah tangga (sampah) yang dihasilkan akibat aktivitas manusia mempunyai banyak dampak pada manusia dan lingkungan sekitar. Masih banyak ditemukan sampah organik dan anorganik yang dihasilkan oleh aktivitas masyarakat di lingkungan sekitar pemukiman warga Desa Kebadongan yang bersumber dari aktifitas rumah tangga. Pelaksanaan penyuluhan dan pemberian pelatihan pengelolaan dan pemanfaatan sampah menggunakan konsep $3 R$ (Reduce, Reuse, Recycle) atau pengurangan, penggunaan kembali dan mendaur ulang sampah adalah salah satu cara yang efektif untuk dapat menciptakan suatu kawasan dengan tingkat pengelolaan sampah mandiri yang akan membantu pemerintah untuk menciptakan lingkungan yang sehat, bersih dan nyaman. Penelitian ini dilakukan dengan tujuan untuk: (1) memberikan pengetahuan kepada masyakat tentang pentingnya memilah sampah organik dan anorganik sebagai kunci awal penerapan konsep $3 R$ dan (2) memberikan pengetahuan kepada masyarakat dalam pengolahan sampah organik menjadi pupuk kompos dan pengolahan sampah anorganik menjadi berbagai jenis kerajinan tangan. Kegiatan penelitian ini dilakukan di Desa Kebadongan pada hari Minggu tanggal 20 Januari 2019 pukul 11.00 bertempat di aula balaidesa dengan menggunakan metode ceramah, demonstrasi dan diskusi. Pelaksanaan kegiatan penelitian dapat diuraikan melalui 3 (tiga) tahapan kegiatan, yaitu persiapan, pelaksanaan dan evaluasi. Hasil nyata yang didapatkan dari kegiatan penyuluhan dan pelatihan pengelolaan sampah menggunakan konsep $3 R$ ini adalah meningkatnya pengetahuan masyarakat tentang sampah. Masyarakat juga menyadari dan mulai membiasakan diri untuk memilah sampah organik dan anorganik sebagai kunci awal penerapan konsep $3 R$. Penggunaan konsep $3 R$ (reuse, reduce, recycle) dapat menginspirasi warga untuk menciptakan suatu kawasan dengan tingkat pengelolaan sampah mandiri yang akan membantu pemerintah untuk menciptakan lingkungan yang sehat, bersih dan nyaman. Selain itu, pengetahuan masyarakat tentang pengelolaan sampah organik dan anorganik juga semakin meningkat.
\end{abstract}

Kata Kunci: Desa Kebadongan, Sampah, 3R (Reduce, Reuse, Recycle) 


\section{A. PENDAhuluan}

Keberadaan limbah rumah tangga (sampah) yang dihasilkan sebagai akibat dari aktivitas manusia mempunyai banyak dampak pada manusia dan lingkungan sekitar. Sampah yang dihasilkan dari aktivitas rumah tangga berbagai macama jenis, seperti organik dan anorganik. Sampah menjadi salah satu permasalahan yang cukup sulit di tangani di Indonesia, salah satunya adalah di Desa Kebadongan, Kecamatan Klirong, Kabupaten Kebumen. Hal ini terjadi karena kebiasaan masyarakatnya sebagai konsumen yang selalu menghasilkan sampah. Aktivitas dan daya beli masyarakat yang semakin tinggi menyebabkan semakin bertambahnya timbunan sampah sebagai sisa aktivitas. Kurangnya kesadaran akan pentingnya kebersihan menjadi faktor yang paling dominan. Keberadaan sampah dalam kehidupan sehari-hari tidak terlepas dari ulah tangan manusia yang membuang sampah sembarangan, mereka menganggap barang yang telah dipakai tidak memiliki kegunaan lagi.

Sampah yang tidak dikelola menyebabkan dampak negatif baik langsung mau pun tidak langsung. Dampak negatif langsung diantaranya lingkungan menjadi kumuh, kotor, menimbulkan bau tak sedap dan berpotensi menjadi sumber penyakit yang akan berdampak bagi kesehatan warga. Volume sampah yang dihasilkan akan terus meningkat seiring dengan berkembangnya jumlah penduduk dan aktivitas masyarakat. Namun sampai saat ini peran serta masyarakat secara umum hanya sebatas pengumpulan dan pembuangan sampah saja.

Kreativitas pemanfaatan barang bekas menjadi kerajinan tangan adalah solusi yang cukup baik untuk mengubah sampah anorganik menjadi menjadi barang yang berguna kembali. Kreativitas dalam diri seseorang dapat ditumbuhkan melalui banyak cara, salah satunya yaitu dengan membuat kerajinan tangan berbahan dasar barang bekas yang berasal dari sampah anorganik seperti plastik, 
kertas, botol bekas, kaleng bekas dan lain-lain. Pemanfaatan sampah anorganik masih jarang dilakukan di Desa Kebadongan yang masyarakatnya kurang memperhatikan hal-hal seperti kreativitas kerajinan tangan dengan memanfaatkan sampah anorganik hasil dari limbah rumah tangga. Dengan adanya kegiatan pelatihan kreativitas pemanfaatan sampah anorganik menjadi berbagai macam jenis kerajinan tangan diharapkan dapat meningkatkan kepedulian masyarakat terhadap lingkungan dengan memanfaatkan sampah hasil limbah rumah tangga. Pemanfaatan sampah daur ulang juga dapat memberikan dampak positif untuk mendorong jiwa entrepreneur masyarakat dengan mengolah sampah anorganik menjadi produk-produk yang berkualitas. Produk-produk yang dihasilkan dari barang-barang bekas ini memiliki nilai jual yang bersaing dipasaran. Sampah yang dihasilkan melalui aktifitas rumah tangga jika dipisahkan kemudian diolah kembali akan menghasilkan nilai ekonomi bagi masyarakat. Sedangkan sampah organik dapat dijadikan sebagai pupuk atau makanan hewan yang bersumber dari limbah sayuran, daun-daunan, buah-buahan yang sudah tua atau sudah busuk.

Keberadaan sampah di Desa Kebadongan, Kecamatan Klirong, Kabupaten Kebumen. Apabila terus dibiarkan maka dapat menimbulkan pencemaran lingkungan dan menggangu kesehatan masyarakat. Limbah rumah tangga atau sampah organik dan anorganik apabila dapat dimanfaatkan dengan baik dapat memebrikan nilai ekonomi bagi masyarakat itu sendiri. Kondisi Desa Kebadongan, Kecamatan Klirong, Kabupaten Kebumen sendiri sebagian besar masyarakatnya mempunyai pekerjaan sebagai seorang petani.

Pekerjaan sebagai seorang petani yang dilakukan oleh warga Desa Kebadongan, Kecamatan Klirong, Kabupaten Kebumen merupakan sumber mata pencaharian sehari-hari. Menurut Adiningsih (2006) penggunaa pupuk organik seperti pupuk hijau, pupuk kandang, jerami telah lama dilakukan petani, namun dengan adanya pupuk kimia berkadar hara tinggi membuat perhatian para petani terhadap peranan pupuk organik sebagai penyubur tanah makin berkurang. Penggunaan pupuk kimia semakin banyak dipergunakan, petani berasumsi semakin banyak pupuk kimia yang digunakan maka semakin banyak hasil panennya. Dengan memanfaatkan sampah hasil olahan dari aktifitas rumah tangga 
dapat mengurangi ketergantungan petani terhadap pupuk kimia, mengatasi kesulitan pupuk dan menciptakan sistem pertanian organik.

Partisipasi masyarakat merupakan aspek terpenting dalam kegiatan pengelolaan sampah. Partisipasi masyarakat akan meningkat apabila masyarakat mengetahui nilai lebih dan keuntungan-keuntungan yang diperolah bagi individu maupun lingkungan mereka sendiri jika melakukan pengelolaan sampah secara mandiri. Suatu kegiatan pengelolaan kebersihan lingkungan, khususnya sampah tidak akan berhasil dengan baik bila hanya mengandalkan peran pemerintah.

Pengenalan dan penerapan konsep 3R (Reduce, Reuse, Recycle) atau pengurangan, penggunaan kembali dan mendaur ulang sampah, merupakan salah satu cara dalam pengelolaan sampah terutama sampah yang dihasilkan dari limbah rumah tangga. Dengan konsep ini masyarakat tidak hanya membuang sampah tapi sekaligus memanfaatkannya. Sudah saatnya masyarakat mengubah paradigma sampah dari barang yang tidak berguna menjadi sesuatu yang dapat dimanfaatkan kembali. Pengelolaan sampah yang paling sederhana seperti memisahkan sampah organik dan anorganik di masyarakat merupakan kunci awal penerapan konsep $3 R$.

Berdasarkan hasil observasi dan wawancara menunjukkan bahwa masih banyak ditemukan sampah organik dan anorganik yang dihasilkan oleh aktivitas masyarakat di lingkungan sekitar pemukiman penduduk yang bersumber dari aktifitas rumah tangga. Sampah yang dihasilkan dari aktivitas sehari-hari oleh penduduk diantaranya terdiri dari berbagai macam sayur-sayuran, botol, kertas, plastik kemasan dan lain-lain. Selain itu, hanya sebagian kecil dari kepala rumah tangga di Desa Kebadongan Kecamatan Klirong Kabupaten Kebumen yang sudah melakukan pemilahan sampah antara sampah basah dan sampah kering, sampah organik dan sampah anoirganik. Pengenalan dan penerapan konsep 3R (Reduce, Reuse, Recycle) atau pengurangan, penggunaan kembali dan mendaur ulang sampah merupakan salah satu cara dalam pengelolaan sampah hasil limbah rumah tangga. Dengan konsep ini masyarakat tidak hanya membuang sampah tapi sekaligus memanfaatkannya. 
Pengurangan sampah plastik menjadi hal yang penting karena sebagian besar wadah yang digunakan dalam aktivitas manusia terbuat dari plastik, sementara plastik sendiri merupakan bahan yang tidak mudah terurai dan memerlukan waktu yang lama sampai puluhan tahun untuk dapat terdekomposisi. Masih sedikitnya partisipasi masyarakat Desa Kebadongan, Kecamatan Klirong, Kabupaten Kebumen terhadap pengelolaan sampah yang berwawasan lingkungan menunjukkan sangat diperlukannya usaha yang intensif dan berkesinambungan untuk meningkatkan partisipasi masyarakat terhadap pengelolaan sampah di lingkungannya secara mandiri.

Melihat permasalahan di atas, maka yang harus dilakukan adalah memberikan sentuhan ilmu atau teknologi pemanfaatan limbah organik dan anorganik kepada masyarakat khususnya yang berada di Desa Kebadongan, Kecamatan Klirong, Kabupaten Kebumen. Masyarakat yang bertempat tinggal di Desa Kebadongan, Kecamatan Klirong, Kabupaten Kebumen dapat dihimpun dalam kelompokkelompok dan selanjutnya diberikan pelatihan-pelatihan tentang keterampilaan membuat berbagai produk-produk dengan bahan dasar limbah organik dan anorganik. Berdasarkan beberapa permasalahan yang telah diuraikan, dapat diketahui bahwa perlu adanya suatu penelitian tentang "Penyuluhan Pengelolaan Sampah dengan Konsep 3R dalam Mengurangi Limbah Rumah Tangga”.

\section{PEMBAHASAN}

\section{a. Definisi, Sumber dan Jenis Sampah}

Kamus Besar Bahasa Indonesia (2008) mengartikan sampah sebagai benda yang dibuang karena tidak terpakai dan tidak dapat digunakan lagi. Manik (2003) mendefenisikan smapah sebagai suatu benda yang tidak digunakan atau tidak dikehendaki dan harus dibuang, yang dihasilkan oleh kegiatan manusia. Sementara didalam UU No 18 Tahun 2008 tentang Pengelolaan Sampah, disebutkan sampah adalah sisa kegiatan sehari hari manusia atau proses alam yang berbentuk padat atau semi padat berupa zat organik atau anorganik bersifat dapat terurai atau tidak dapat terurai yang dianggap sudah tidak berguna lagi dan dibuang kelingkungan (Slamet, 2002). 
Berdasarkan definisi ini maka sampah dapat berupa sampah yang mudah membusuk seperti sampah dapur, daun-daun kering, kotoran hewan dan sejenisnya. Sedangkan sampah yang tidak mudah terurai atau membusuk seperti sampah plastik, logam, gelas, karet dan lain-lain. Menurut Gelbert, Prihanto dan Suprihatin (1996), sumber-sumber timbulan sampah adalah sebagai berikut:

\section{Sampah dari permukiman}

Sampah ini berupa sampah rumah tangga yang dihasilkan dari suatu kawasan permukiman. Jenis sampah ini biasanya cenderung bersifat seperti organik seperti sisa makanan, atau sampah basah dari dapur. Sampah anorganik seperti plastik, kaleng dan lainlain juga dihasilkan dalam jumlah yang lebih sedikit dibanding sampah organik.

2. Sampah dari tempat-tempat umum dan perdagangan

Tempat-tempat umum adalah tempat yang dimungkinkan banyaknya orang berkumpul dan melakukan kegiatan. Tempat-tempat tersebut berpotensi besar menghasilkan sampat termasuk tempat perdagangan seperti pertokoan dan pasar. Jenis sampah yang dihasilkan umumnya berupa sisa-sisa makanan, sampah kering, plastik dan kaleng-kaleng.

3. Sampah dari sarana pelayanan masyarakat milik pemerintah

Sampah ini berasal dari tempat-tempat pelayanan masyarakat milik pemerintah seperti rumah sakit, tempat hiburan, pantai, mesjid, perkantoran dan sarana pemerintah lainnya. Jenis sampah yang dihasilkan dapat berupa sampah kering dan sampah basah.

4. Sampah dari industri

Sampah ini berasal dari industri-industri dan berbagai kegiatan industri baik yang termasuk distribusi atau pun proses suatu bahan mentah. Sampah yang dihasilkan dari tempat ini biasanya sampah basah, sampah kering, dan sisa bahan bangunan atau kegiatan industri.

5. Sampah pertanian

Sampah ini dihasilkan dari tanaman atau binatang di daerah pertanian misalnya sampah dari kebun, kandang, atau sawah. Sampah yang dihasilkan umumnya sampah organik. 
Menurut Gelbert, Prihanto dan Suprihatin (1996) sampah yang dihasilkan dari berbagai sumber tersebut berdasarkan bahan asalnya dibedakan menjadi dua yaitu:

1. Sampah organik

Sampah organik adalah sampah yang dihasilkan dari bahan-bahan hayati yang dapat didegradasi oleh mikroba atau bersifat biodegradable. Sampah ini dengan mudah dapat diuraikan melalui proses alami. Sampah organik ini diantaranya sampah dari dapur, sisa-sisa makanan, pembungkus (selain plastik, karet, styrofoam dan sejenisnya), kulit buah, daun dan ranting.

2. Sampah anorganik

Sampah anorganik adalah sampah yang dihasilkan dari bahan-bahan non hayati baik berupa produk sintetik amupun hasil proses teknologi pengolahan bahan tambang. Sampah kelompok ini sebagain besar tidak dapat diurai oleh mikroorganisme secara keseluruhan (unbiodegradable). Sementara, sebagian lainnya hanya dapat diuraikan dalam waktu yang lama. Contoh sampah jenis ini misalnya botol plastik, botol gelas dan kaleng.

Berdasarkan keadaan fisiknya sampah dibedakan menjadi sampah basah dan sampah kering. Sampah basah umumnya mempunyai kandungan air yang tinggi sehingga cepat membusuk, misalnya sisa-sisa makanan. Sedangkan sampah kering merupakan sampah yang tidak banyak mengandung air dan tidak mudah lapuk atau membusuk. Contoh jenis sampah ini adalah sampah plastik, kaca, kertas dan kaleng.

\section{b. Pengelolaan Sampah}

Undang-Undang No 18 tahun 2008 tentang pengelolaan sampah beserta Peraturan Pemerintah No 81 tahun 2012 mengamanatkan perlunya perubahan paradigma yang mendasar dalam pengelolaan sampah yaitu dari paradigma kumpul-angkut-buang menjadi pengolahan yang bertumpu pada pengurangan sampah dan penanganan sampah. Kegiatan pengurangan sampah bermakna agar seluruh lapisan masyarakat, baik pemerintah, dunia usaha maupun masyarakat luas melaksanakan pembatasan timbulan sampah, pendauran ulang dan pemanfaatan kembali sampah atau yang lebih dikenal dengan konsep $3 \mathrm{R}$ (Kementrian Lingkungan Hidup, 2012). Pengertian pengelolaan sampah 3R secara 
umum adalah upaya pengurangan pembuangan sampah, melalui kegiatan menggunakan kembali (reuse), mengurangi (reduce), dan mendaur ulang (recycle). Konsep tersebut dapat dijabarkan sebagai berikut:

1. Reuse (menggunakan kembali), yaitu penggunaan kembali sampah secara langsung baik untuk fungsi yang sama maupun fungsi lain. Contoh yang dapat dilakukan di ruma tangga misalnya penggunaan kembali wadah bekas botol madu untuk wadah pernak-pernik, kaleng cat untuk tempat sampah, botol plastik untuk pot bunga dan sebagainya.

2. Reduce (mengurangi), yaitu mengurangi segala sesuatu yang menyebabkan timbulnya sampah. Hal ini dapat dilakukan misalnya dengan menggunakan kantong yang tahan lama untuk belanja kebutuhan sehari-hari, menggunakan produk yang bisa diisi ulang, mengurangi pemakaian bahan sekali pakai seperti tisue dengan serbet atau sapu tangan, membawa wadah makan atau minum sendiri dan lain-lain.

3. Recycle (daur ulang), yaitu memanfaatkan kembali sampah setelah mengalami proses pengolahan. Hal yang dapat dikerjakan untuk konsep ini dalam skala rumah tangga diantaranya selalu memilih produk atau kemasan yang memiliki tanda bisa atau mudah didaur ulang, membuat kompos dari sampah organik yang dihasilkan, membuat sampah kaleng menjadi barang lain yang lebih bermanfaat.

Pengelolaan sampah dengan konsep 3R ini membutuhkan partisipasi masyarakat sebagai bagian yang sangat penting. Partisipasi masyarakat merupakan suatu keterlibatan masyarakat untuk berperan secara aktif dalam suatu kegiatan yang bersih dan sehat, khususnya dalam melakukan pengelolaan sampah.

Karena itu diperlukan penggalangan partisipasi publik yang lebih aktif untuk mengelola sampahnya masing-masing. Pengelolaan sampah dengan konsep 3R dapat dilakukukan mulai dari kawasan perumahan tingkat RT, RW atau kelurahan. Dengan konsep ini lingkungan menjadi sehat dan bersih melalui kegiatan daur ulang baik sampah organik mau pun anorganik. Untuk pengelolaan sampah di pemukiman dapat dimulai dengan memilah sampah sederhana menjadi 
sampah organik dan anorganik. Salah satu usaha pemanfaatan limbah tersebut adalah dengan menjadikannya kompos. Sriharti, Takiyah Salim, 2010 telah melakukan pembuatan kompos dengan bahan sampah taman (rumput-rumputan). Sisa makanan, sisa sayuran dari proses memasak dan kulit buah dikumpulkan dan dipisahkan dari sampah anorganik berupa sampah plastik. Sampah berupa batang tanaman, sayuran daun, atau kulit buah yang keras agar dirajang terlebih dahulu.

Sampah yang telah terkumpul kemudian dicampur dengan sedikit tanah atau kompos setengah matang atau kotoran hewan dan kemudian diaduk sampai rata. Proses pengomposan agar dapat berjalan dengan lebih cepat dan efisien dilakukan dengan menambahkan mikroorganisme perombak bahan organik atau aktivator. EM4 merupakan salah satu jenis aktivator yang dapat digunakan untuk mempercepat proses pembuatan pupuk kompos.

Hal ini sejalan dengan penelitian yang telah dilakukan oleh Rahmawati dan Dony tahun 2014 yang berjudul "Pembuatan Pupuk Organik Berbahan Sampah Organik Rumah Tangga Dengan Penambahan Aktivator EM4 di Daerah Kayu Tangi" menjelaskan bahwa pembuatan kompos dari sampah organik rumah tangga dapat dipercepat dengan bantuan aktivator EM4 (effective mikroorganisme 4). EM4 ditambahkan sebagai mikroorganisme starternya untuk mempercepat proses pengomposan.

Sampah anorganik dipilah kembali, sebagian dapat dijadikan barang kerajinan tangan, dan sebagian dapat dijual ke Bank Sampah atau pengepul untuk proses daur ulang. Selain itu, sampah anorganik kering seperti bungkus plastik kopi, makanan, minuman, dan lain-lain dapat digunakan untuk membuat bermacammacam barang bermacam-macam kerajinan tangan seperti pot, tas, tempat tissue, bunga, cindera mata dan lain-lain yang dapat digunakan sendiri atau pun dijual melalui kelompok PKK, pameran, atau ke toko-toko souvenir.

Sampah plastik merupakan sampah yang tidak mudah terurai, diperlukan waktu yang lama bahkan sampai puluhan tahun untuk bisa menguraikannya. Sampah organik lainnya seperti sampah plastik botol minuman, kaleng, kertas, aluminium foil dan lain-lain dapat dikumpulkan, yang selanjutnya dapat diberikan 
kepada pemulung atau dijual langsung ke pengepul untuk dijadikan produk daur ulang yang bermanfaat.

\section{E. HASIL PENELITIAN}

Kegiatan penelitian ini dilaksanakan di Desa Kebadongan, Kecamatan Klirong, Kabupaten Kebumen. Terlaksananya kegiatan ini sesuai dengan jadwal yang telah ditetapkan dan disepakati oleh pemerintah desa dan juga peserta penyuluhan tentang pemanfaatan sampah (limbah rumah tangga) sebelum kegiatan ini dimulai.

Kegiatan penelitian ini dimulai dengan melakukan tahap persiapan, pada tahap ini dilakukan observasi dan permohonan izin kepada perangkat Desa Kebadongan, Kecamatan Klirong, Kabupaten Kebumen. sebagai tempat pelaksanaan kegiatan penelitian ini. Selain itu pada tahap persiapan juga dilakukan kegiatan observasi untuk mencari informasi jumlah peserta dan kegiatan peserta sebelum diadakan pelatihan kegiatan pemanfaatan sampah (limnbah rumah tangga) kepada warga Desa Kebadongan, Kecamatan Klirong, Kabupaten Kebumen. Setelah waktu pelaksanaan disepakati, peneliti menyusun jadwal pelaksanaan dan membuat kesepakan dengan beberapa pihak yang terkait.

Tahap pelaksanaan kegiatan dimulai dengan tahapan sosialisasi kegiatan. Dalam tahapan persiapan, tim pelaksana kegiatan juga melakukan brifing untuk penyiapan bahan-bahan yang dibutuhkan pada saat kegiatan penyuluhan atau pelatihan, menyiapkan para peserta pelatihan, menyiapkan materi pelatihan yang berhubungan dengan konsep 3R (Reduce, Reuse, Recycle) atau pengurangan, penggunaan kembali dan mendaur ulang sampah (sampah anorganik menjadi beberapa jenis kerajinan tangan dan sampah organik menjadi pupuk kompos menggunakan aktivator EM4).

Tahapan pelaksanaan kegiatan dilaksanakan sesuai dengan waktu yang telah di sepakati yaitu pada hari Minggu tanggal 20 Januari 2019 bertempat di aula balai Desa Kebadongan, Kecamatan Klirong, Kabupaten Kebumen. Tahapan pelaksanan selanjutnya yaitu penyampaian materi yang dilakukan dengan menggunakan metode ceramah. Metode demonstrasi digunakan untuk 
mempraktekan bagaimana cara mengolah sampah organik menjadi pupuk kompos dengan aktivator EM4 dan sampah anorganik berbahan dasar kertas dan plastik menjadi beberapa barang yang bermanfaat dalam kehidupan sehari-hari. Tahapan pelatihan diberikan kepada setiap peserta berupa uraian atau langkah-langkah pembuatan pupuk dari sampah organik dan pembuatan produk dari sampah anorganik berbahan dasar plastik dan kertas.

Arahan dan tanya jawab berlangsung pada saat pelaksanaan kegiatan penyuluhan atau pelatihan, instruktur menjelaskan langkah-langkah beberapa cara pengelolaan sampah (limbah rumah tangga) baik yang organik maupun anorganik dan langsung mendemostrasikannya kepada peserta. Pelatihan berlangsung mulai pukul 11.00 sampai dengan selesai yang berlokasi di aula balaidesa Kebadongan, Kecamatan Klirong, Kabupaten Kebumen.

Materi yang disampaikan pada kegiatan ini berkaitan dengan substansi pertanyaan yang diajukan di atas yang meliputi pengetahuan tentang jenis-jenis sampah, cara memilahnya, permasalahannya dan pengelolaannya. Melalui kegiatan ini diharapkan tumbuhnya kesadaran masyarakat untuk memilah sampah, mengelola sampah dan memanfaatkannya kembali sehingga lingkungan mereka dapat bebas dari sampah, penyakit yang disebabkan sampah dan lingkungan menjadi asri. Kegiatan ini dilakukan untuk meningkatkan pengetahuan dan menumbuhkan kesadaran masyarakat tentang pentingnya pengelolaan sampah di lingkungan masing-masing secara mandiri. Meningkatnya jumlah penduduk dan perekonomian seiring dengan meningkatnya barang yang dibeli, yang berarti semakin meningkatnya sampah yang dihasilkan.

Pelaksanaan kegiatan dapat diuraikan melalui 3 (tiga) tahapan. Tahapan pertama adalah perencanaan, tahapan kedua adalah memberikan penyuluhan materi tentang konsep 3R (Reduce, Reuse, Recycle) atau pengurangan, penggunaan kembali dan mendaur ulang sampah (sampah anorganik menjadi beberapa jenis kerajinan tangan dan sampah organik menjadi pupuk kompos menggunakan aktivator EM4) dan memberikan pelatihan tentang tata cara mendaur ulang sampah anorganik berbahan dasar plastik dan kertas menjadi berbagai macam kerajinan, tahapan terakhir atau tahapan ketiga adalah evaluasi. 
Pada tahap persiapan yang merupakan perencanaan kegiatan penyuluhan tentang pengelolaan sampah menggunakan konsep 3R dilakukan beberapa kegiatan sebagai berikut:

1. Koordinasi dengan pihak desa lokasi tempat dilakukan atau dilaksanakannya penelitian

Koordinasi dengan pihak desa dilakukan dengan Kepala Desa dan Pemerintah Desa Kebadongan, Kecamatan Klirong, Kabupaten Kebumen. Pihak desa mendukung kegiatan yang dilakukan di Desa Kebadongan terkait dengan penyuluhan dan pelatihan pengelolaan sampah menggunakan konsep 3R.

2. Penetapan waktu pelatihan

Pelaksanaan pelatihan berdasarkan kesepakatan dengan Kepala Desa, Pemerintah Desa dan beberapa pihak terkait di Desa Kebadongan dilakukan di aula balaidesa pada hari Minggu tanggal 20 Januari 2019.

3. Penentuan sasaran dan target peserta pelatihan

Dari koordinasi dengan Kepala Desa, Pemerintah Desa dan beberapa pihak terkait maka sasaran pelatihan adalah masyarakat Desa Kebadongan, yaitu dengan target peserta pelatihan sebanyak 50 orang.

4. Perencanaan materi pelatihan

Materi pelatihan yang telah direncanakan oleh tim pengabdi meliputi pengetahuan tentang konsep 3R (Reduce, Reuse, Recycle) atau pengurangan, penggunaan kembali dan mendaur ulang sampah (sampah anorganik menjadi beberapa jenis kerajinan tangan dan sampah organik menjadi pupuk kompos menggunakan aktivator EM4).

Tahapan persiapan di atas selanjutnya diikuti dengan tahap pelaksanaan. Pada tahap pelaksanaan kegiatan dapat diuraikan bahwa:

1. Kegiatan penyuluhan pengelolaan sampah dengan konsep $3 \mathrm{R}$ dalam mengurangi limbah rumah tangga dilaksanakan pada hari Minggu tanggal 20 Januari 2019.

2. Kegiatan penyuluhan pengelolaan sampah dengan konsep $3 \mathrm{R}$ dalam mengurangi limbah rumah tangga dihadiri oleh 78 peserta yang berrasal dari masyarakat Desa Kebadongan, Kecamatan Klirong, Kabupaten Kebumen. 
3. Peserta penyuluhan terlihat sangat antusias mengikuti acara penyuluhan ini. Antusiasme masyarakat terlihat dari banyaknya peserta yang hadir pada acara penyuluhan tentang pengelolaan sampah dengan konsep 3R (Reduce, Reuse, Recycle) atau pengurangan, penggunaan kembali dan mendaur ulang sampah sebagai upaya pemberdayaan masyarakat untuk menjaga kesehatan. Selain itu, antusiasme masyarakat juga dapat terlihat dari kegiatan diskusi yang hangat.

4. Materi pelatihan berupa: (a) pengetahuan tentang jenis-jenis sampah, (b) pengetahuan tentang cara memilah sampah sampah, (c) pengetahuan tentang cara mengurangi sampah, (d) pengetahuan tentang beberapa jenis sampah yang dapat digunakan kembali, (e) pengetahuan dan praktik tentang tata cara pengolahan sampah organik maupun anorganik. Semua materi tersebut dapat disampaikan oleh tim pengabdi dengan waktu terbatas.

Tahapan pelaksanaan di atas selanjutnya diikuti dengan tahap evaluasi yang bertujuan untuk mengetahui efektivitas kegiatan penyuluhan dan pelatihan pengelolaan sampah menggunakan konsep 3R. Perlunya evaluasi dilakukan untuk melihat hasil dari pelaksanaan pelatihan yang dilakukan setelah semua tahap persiapan dan pelaksanaan telah terlaksana yaitu dengan meminta kritik dan saran dari masyarakat.

Evaluasi dilakukan untuk mengetahui tingkat minat atau perhatian peserta pada pelaksanaan kegiatan. Selain itu, kegiatan evaluasi juga dilakukan mengetahui ada tidaknya penambahan pengetahuan dan kesadaran masyarakat tentang konsep 3R (Reduce, Reuse, Recycle) atau pengurangan, penggunaan kembali dan mendaur ulang sampah. Hasil evaluasi ini diharapkan akan memberikan masukan untuk perbaikan pada kegiatan berikutnya.

Hasil nyata yang didapatkan dari kegiatan penyuluhan dan pelatihan pengelolaan sampah menggunakan konsep $3 \mathrm{R}$ ini adalah terdapat peningkatan pengetahuan masyarakat Desa Kebadongan, Kecamatan Klirong, Kabupaten Kebumen tentang konsep 3R (Reduce, Reuse, Recycle) atau pengurangan, penggunaan kembali dan mendaur ulang sampah. Selain itu, masyarakat Desa Kebadongan juga mengetahui tentang jenis-jenis sampah, cara memilah sampah 
sampah, cara mengurangi sampah, beberapa jenis sampah yang dapat digunakan kembali, dan tata cara pengolahan sampah organik maupun anorganik. Masyarakat juga dapat mengurangi kebiasaan untuk membuang sampah sembarangan. Selain itu, beberapa masyarakat juga menyadari dan mulai membiasakan diri untuk memilah sampah organik dan anorganik sebagai kunci awal penerapan konsep 3R. Selain itu, pengetahuan masyarakat tentang pengolahan sampah organik dan anorganik juga semakin meningkat.

Secara keseluruhan kegiatan pelatihan "Penyuluhan Pengelolaan Sampah dengan Konsep 3R dalam Mengurangi Limbah Rumah Tangga" dapat dikatakan baik dan berhasil dilihat besarnya animo peserta untuk mengikuti kegiatan sosialisasi atau penyuluhan tentang konsep 3R (Reduce, Reuse, Recycle) atau pengurangan, penggunaan kembali dan mendaur ulang sampah yang berjumlah 78 orang melebihi target sasaran dari kegiatan penyuluhan dan pelatihan pengelolaan sampah menggunakan konsep 3R yang dilaksanakan dan juga antusias peserta untuk dapat mengelola sampah hasil limbah rumah tangga yang mereka kumpulkan setiap hari agar lingkungan tempat tinggal menjadi sehat, asri dan bebas sampah dapat terwujud.

\section{F. Kesimpulan}

Secara keseluruhan kegiatan pelatihan pengelolaan sampah dengan konsep 3R di Desa Kebadongan, Kecamatan Klirong, Kabupaten Kebumen berjalan dengan baik dan lancar. Kegiatan "Penyuluhan Pengelolaan Sampah dengan Konsep 3R dalam Mengurangi Limbah Rumah Tangga” di Desa Kebadongan dapat memberikan dan menambah pengetahuan tentang sampah serta meningkatkan kesadaran masyakat untuk memilah sampah organik dan anorganik sebagai kunci awal penerapan konsep 3R untuk menciptakan suatu kawasan dengan tingkat pengelolaan sampah mandiri yang akan membantu pemerintah untuk menciptakan lingkungan yang sehat, bersih dan nyaman. Selain itu, kegiatan "Penyuluhan Pengelolaan Sampah dengan Konsep 3R dalam Mengurangi Limbah Rumah Tangga” di Desa Kebadongan dapat memberikan dan menambah pengetahuan masyarakat dalam pengolahan sampah organik menjadi 
pupuk kompos dengan bantuan aktivator EM4 dan pengolahan sampah anorganik menjadi berbagai jenis kerajinan tangan.

\section{G. Saran}

Merubah kebiasaan masyarakat yang membuang sampahnya pada satu wadah menjadi beberapa wadah bukanlah hal yang mudah. Demikian juga dengan merubah paradigma masyarakat terhadap sampah yang awalnya hanya sebagai barang yang sudah tidak dapat dipakai lagi menjadi barang yang masih mempunyai nilai ekonomi bukan hal yang mudah. Karena itu diperlukan pendampingan, monitoring atau survei dan evaluasi yang berkelanjutan agar masyarakat dapat menerapkan pengetahuan yang mereka miliki sehingga dapat menjadi kebiasaan yang mereka lakukan dalam kehidupan sehari-hari terkait dengan konsep 3R (Reduce, Reuse, Recycle) atau pengurangan, penggunaan kembali dan mendaur ulang sampah. Kegiatan serupa juga perlu dilakukan di tempat lain sehingga pengelolaan sampah benar-benar menjadi pengelolaan sampah yang berbasis partisipasi masyarkat.

\section{DAFTAR PUSTAKA}

Adiningsih, S. 2006. Peranan Bahan/Pupuk Organik dalam Menunjang Peningkatan Produktivitas Lahan Pertanian. A. Sulaeman. A. Mahdi. A.K. Seta. R. Prihandarini. Z. Soedjais (Eds). Prosiding Seminar Nasional MAPORINA, pp. 37-48

Departemen Pendidikan Nasional, Pusat Bahasa. 2008. Kamus Besar Bahasa Indonesia. Jakarta: Balai Pustaka.

Gelbert M., Prihanto D., dan Suprihatin A. 1996. Konsep Pendidikan Lingkungan Hidup dan "Wall Chart". Buku Panduan Pendidikan Lingkungan Hidup. Malang: PPPGT/VEDC.

Kementrian Lingkungan Hidup. 2012. Profil Bank Sampah. Malang: Rapat Kerja Nasional Bank Sampah.

Manik, K.E.S., 2003. Pengelolaan Lingkungan Hidup. Jakarta: Djambatan.

Rahmawanti, N. \& Dony, N. 2014. Pembuatan Pupuk Organik Berbahan Sampah Organik Rumah Tangga Dengan Penambahan Aktivator Em4 di Daerah Kayu Tangi. Jurnal Ziraa'ah, 39 (1), pp. 1-7. 
\begin{tabular}{l|l|l} 
Jurnal Cakrawala: Studi Manajemen Pendidikan Islam dan Studi & Vol.4 No.2 Th 2020
\end{tabular} Sosial P-ISSN: 2580-9385, E-ISSN: 2581-0197 http:/ / ejournal.iainu-kebumen.ac.id/index.php/cka/ index

Slamet J,S, 2002. Kesehatan Lingkungan. Gadjah Mada Universty Press, Yogyakarta.

Sriharti, Takiyah Salim. 2010. Pemanfaatan Sampah Taman (Rumput-Rumputan) Untuk Pembuatan Kompos. Balai Besar Pengembangan Teknologi Tepat Guna LIPI. 